\title{
Effects of a nutraceutical combination of monacolin, $\gamma$-oryzanol and $\gamma$-aminobutyric acid on lipid profile and C-reactive protein in mice
}

\author{
Giuseppe Derosa ${ }^{1,2,3}$, Pamela Maffioli ${ }^{1}$, Angela D’Angelo ${ }^{1,3}$, Rosario Russo ${ }^{4}$
}

\begin{abstract}
${ }^{1}$ Centre of Diabetes, Metabolic Diseases and Dyslipidemias, Department of Internal Medicine and Therapeutics, University of Pavia and Fondazione IRCCS Policlinico San Matteo, Pavia, Italy

${ }^{2}$ Centre for Prevention, Surveillance, Diagnosis and Treatment of Rare Diseases, Fondazione IRCCS Policlinico San Matteo, Pavia, Italy

${ }^{3}$ Laboratory of Molecular Medicine, University of Pavia, Pavia, Italy

${ }^{4}$ Giellepi S.p.A. Health Science, Lissone (MB), Italy
\end{abstract}

Submitted: 7 January 2018

Accepted: 25 February 2018

Arch Med Sci 2019; 15 (3): 792-796

DOI: https://doi.org/10.5114/aoms.2018.75193

Copyright $\odot 2018$ Termedia \& Banach

\begin{abstract}
Introduction: The aim of this study was to evaluate the efficacy of two nutraceutical agents aimed to improve lipid profile in a sample of mice.

Material and methods: Fifty mice were randomly divided into four groups. Control mice were fed a standard diet (SD), while the other three groups were fed with a high-fat diet (HFD) for 4 weeks. At the end of the run-in period, mice fed with the SD continued to follow the SD, while mice fed with the HFD were divided into three groups: one continued with the HFD, one continued to follow the HFD + a blend of natural components derived from rice and fermented rice (monacolin $\mathrm{K} 3 \%, \gamma$-oryzanol, and $\gamma$-aminobutyric acid) (S1), and the other one followed the HFD + one nutraceutical containing monacolin $\mathrm{K} 3 \%$ alone for 24 weeks.

Results: The results showed that mice treated with HFD + S1 and HFD + S2 had lower levels of TC compared to mice fed with the HFD alone $(p<0.01$, and $p<0.05$, respectively). Moreover, mice treated with HFD + S1 had lower TC and LDL-C levels compared to mice fed with HFD + S2 $(p<0.05)$. Mice treated with $\mathrm{HFD}+\mathrm{S} 1$ or S2 had lower Tg levels compared to mice fed with the HFD $(p<0.05)$. Conclusions: We can conclude that a combination of monacolin $\mathrm{K} 3 \%, \gamma$-oryzanol, and $\gamma$-aminobutyric acid is more effective than monacolin $\mathrm{K} 3 \%$ alone in reducing the negative effects of a HFD in a sample of specific pathogen-free mice.
\end{abstract}

Key words: diet, lipid profile, mice, monacolin K, nutraceutical.

\section{Introduction}

Cardiovascular disease, and in particular coronary heart disease (CHD), is the main cause of mortality in developed countries [1]. In atherosclerosis development, cholesterol, and in particular low-density lipoprotein $(\mathrm{LDL})$ cholesterol, plays the main role: usually atherosclerosis begins with endothelial damage caused by high blood pressure, smoking, or high cholesterol. The cornerstone of hypolipidemic treatment should be appropriated lifestyle modifications and statin treatment, or 3-hydroxy-3-methyl-glutaryl-coenzyme A (HMG-CoA) reductase inhibitors [2].

\author{
Corresponding author: \\ Giuseppe Derosa MD, PhD, \\ FESC \\ Department of Internal \\ Medicine and Therapeutics \\ University of Pavia \\ and Fondazione IRCCS \\ Policlinico San Matteo \\ P.le C. Golgi 2 \\ 27100 Pavia, Italy \\ Phone: +390382526217 \\ Fax: +390382 526259 \\ E-mail: giuseppe.derosa@ \\ unipv.it
}


Statins are demonstrably effective in reducing cholesterol [3], but they also have some potential adverse effects, including muscle pain with creatine phosphokinase (CPK) elevation, fatigue and weakness, and liver transaminases increase [4].

The incidence of adverse events is dose related; the higher the dose of statin is, the more frequent can be the adverse events. Because of those adverse events, patients may seek alternative therapies to manage their hypercholesterolemia, including newer hypolipidemic therapies such as PCSK9 inhibitors, even if their use is limited by the high cost.

For all these reasons, in recent years, the nutraceutical market has rapidly increased. Nutraceuticals are dietary supplements. They contain a concentrated form of a presumed bioactive substance originally derived from a food, but now present in a nonfood matrix, and used to enhance health in dosages exceeding those obtainable from normal foods [5]. Several substances have shown positive benefits for lipid profile, such as Berberis aristata, omega-3, krill oil, and cinnamon [6-11].

In particular, in this study we focused our attention on two nutraceutical combinations aimed to improve lipid profile, one called Rossopuro Forte (S1), a blend of natural components derived from rice and fermented rice (monacolin $\mathrm{K} 3 \%$, $\gamma$-oryzanol, and $\gamma$-aminobutyric acid) developed by Giellepi S.p.A. (Lissone, Monza MB, Italy) and one called Rossopuro (S2) containing monacolin K $3 \%$ alone.

In this context, we planned a study to evaluate the efficacy and safety of the two nutraceutical agents in a sample of C57BL/6J mice fed with a standard diet (SD), or high-fat diet (HFD), or HFD with the addition of S1 or S2. The primary outcomes were the effects of these nutraceutical combinations on the lipid profile; the secondary outcomes were considered the changes in C-reactive protein (CRP).

\section{Material and methods}

\section{Study design}

Principles of good laboratory animal care were followed and animal experimentation was in compliance with specific national and international laws and regulations.

The authorization to use animals in Biogem laboratories (Ariano Irpino, Avellino, Italy) was obtained from the Italian Health Authority. The care and husbandry of animals were in accordance with European Directive no. 2010/63 and with the Italian Regulatory system (D.L. vo no. 26, March $\left.4^{\text {th }}, 2014\right)$. All parts of this study concerning animal care have been approved by the official Biogem veterinarian.

\section{Animals}

Specific pathogen-free 4-week-old male C57BL/6J mice purchased from Charles River Laboratories International, Inc. were allowed to acclimate for 1 week before use. Mice were allowed access to food and water ad libitum. The animal room was maintained at a temperature of $20 \pm 2^{\circ} \mathrm{C}$, humidity of $45 \pm 10 \%$ and a 12 -h light/dark cycle. Their care and handling were in accordance with the provision of the European Union Council Directive 2010/63 UE, recognized and adopted by the Italian Government (Decree No. 26/2014).

\section{Treatments}

Mice were randomly separated into four groups. Control mice were fed a standard diet (SD) (D12450B; Research Diets, Inc., New Brunswick, NJ, USA), while the other three groups of mice were all fed a high-fat diet (HFD) (D12492; Research Diets, Inc.) for 4 weeks, in a run-in period. The composition of each diet is listed in Tables I and II. At the end of the run-in period, mice fed with the SD diet continued to follow the SD, while mice fed with the HFD were divided into three groups: one group continued with the HFD, one continued to follow HFD $+\mathrm{S} 1$, and the other one continued to follow HFD + S2 for 24 weeks.

\section{Assessments}

Body weight was recorded twice a week and food intake three times a week. At the end of the experiment, blood collected from the posterior vena cava and plasma was prepared for biochemical analysis. We evaluated at the baseline and after 24 weeks the following parameters: weight, blood glucose, total cholesterol (TC), triglycerides (Tg), high-density lipoprotein cholesterol (HDL-C), low-density lipoprotein cholesterol (LDL-C), C-reactive protein (CRP).

The levels of TC, Tg, HDL-C, and LDL-C in plasma were measured using a Beckman Coulter AU5421 (Beckman Coulter, Fullerton, CA, USA).

C-reactive protein were assayed using an ELISA kit (Boster Biological Technology Co., Ltd., Pleasanton, CA, USA) according to the manufacturer's instructions.

\section{Statistical analysis}

Statistical analysis was performed using the unpaired t-test or an analysis of variance (ANOVA) to analyze continuous laboratory measurements and to perform comparisons among the study groups. (Graph Pad Prism 6). Data are presented as mean \pm standard deviation. For all statistical analyses, $p<0.05$ was considered statistically significant. 
Table I. Standard diet description with 10\% kcal \% fat

\begin{tabular}{|c|c|c|}
\hline Product \# D12450B & g (\%) & kcal (\%) \\
\hline Protein & 19.2 & 20 \\
\hline Carbohydrate & 67.3 & 70 \\
\hline Fat & 43 & 10 \\
\hline Total & & 100 \\
\hline $\mathrm{kcal} / \mathrm{g}$ & 3.85 & \\
\hline Ingredient & g (\%) & kcal (\%) \\
\hline Casein, 30 Mesh & 200 & 800 \\
\hline L-cystine & 3 & 12 \\
\hline Corn starch & 315 & 1260 \\
\hline Maltodextrin 10 & 35 & 140 \\
\hline Sucrose & 350 & 1400 \\
\hline Cellulose, BW200 & 50 & 0 \\
\hline Soybean oil & 25 & 225 \\
\hline Lard* & 20 & 180 \\
\hline Mineral Mix S10026 & 10 & 0 \\
\hline Dicalcium phosphate & 13 & 0 \\
\hline Calcium carbonate & 5.5 & 0 \\
\hline Potassium citrate, $1 \mathrm{H}_{2} \mathrm{O}$ & 16.5 & 0 \\
\hline Vitamin Mix V 10001 & 10 & 40 \\
\hline Choline bitartrate & 2 & 0 \\
\hline FD\&C Yellow Dye \#5 & 0.05 & 0 \\
\hline Total & 1055.05 & 4057 \\
\hline
\end{tabular}

*Typical analysis of cholesterol in lard $=0.72 \mathrm{mg} / \mathrm{g}$, cholesterol $(\mathrm{mg}) / 4057 \mathrm{kcal}=14.4$, cholesterol $(\mathrm{mg}) / \mathrm{kg}=13.6$.

\section{Results}

\section{Study sample}

A total of 50 mice were enrolled in the study. Of these, all mice completed the study. The characteristics of the mice population at study entry are shown in Table III.

\section{Body weight}

As shown in Table III, at the end of the study, animals fed with the HFD had a larger body weight increase compared with animals fed with the SD $(p<0.05)$, without differences among the group treated with HFD and the groups treated with HFD and S1 or S2.

\section{Blood glucose}

No variation of $B G$ was recorded during the study among groups.
Table II. High-fat diet description with $60 \% \mathrm{kcal} \%$ fat

\begin{tabular}{|c|c|c|}
\hline Product \# D12492 & $\mathrm{g}(\%)$ & kcal (\%) \\
\hline Protein & 26.2 & 20 \\
\hline Carbohydrate & 26.3 & 20 \\
\hline Fat & 34.9 & 60 \\
\hline Total & & 100 \\
\hline $\mathrm{kcal} / \mathrm{g}$ & 5.24 & \\
\hline Ingredient & g (\%) & kcal (\%) \\
\hline Casein, 30 Mesh & 200 & 800 \\
\hline L-cystine & 3 & 12 \\
\hline Corn starch & 0 & 0 \\
\hline Maltodextrin 10 & 125 & 500 \\
\hline Sucrose & 68.8 & 275.2 \\
\hline Cellulose, BW200 & 50 & 0 \\
\hline Soybean oil & 25 & 225 \\
\hline Lard* $^{*}$ & 245 & 2205 \\
\hline Mineral Mix S10026 & 10 & 0 \\
\hline Dicalcium phosphate & 13 & 0 \\
\hline Calcium carbonate & 5.5 & 0 \\
\hline Potassium citrate, $1 \mathrm{H}_{2} \mathrm{O}$ & 16.5 & 0 \\
\hline Vitamin Mix V 10001 & 10 & 40 \\
\hline Choline bitartrate & 2 & 0 \\
\hline FD\&C Blue Dye \#1 & 0.05 & 0 \\
\hline Total & 773.85 & 4057 \\
\hline
\end{tabular}

${ }^{*}$ Typical analysis of cholesterol in lard $=0.72 \mathrm{mg} / \mathrm{g}$, cholesterol $(\mathrm{mg}) / 4057 \mathrm{kcal}=216.4$, cholesterol $(\mathrm{mg}) / \mathrm{kg}=279.6$.

\section{Lipid profile}

After 24 weeks, mice fed with the HFD alone showed an increase of TC $(p<0.05)$ compared to the group fed with the SD. However, mice treated with HFD + S1 and HFD + S2 showed lower levels of TC compared to mice fed with the HFD alone ( $p<0.01$ vs. HFD at 24 weeks for $\mathrm{HFD}+\mathrm{S} 1$, and $p<0.05$ vs. HFD at 24 weeks for HFD + S2). Moreover, mice treated with HFD + S1 had lower TC levels compared to mice fed with $\mathrm{HFD}+\mathrm{S} 2$ ( $p<0.05$ vs. HFD + S2 at 24 weeks). A similar trend was recorded for $L D L-C$, while no variations were recorded for $\mathrm{HDL}-\mathrm{C}$ during the study. Triglycerides recorded after 24 weeks of the HFD were higher compared to mice fed with the SD. Moreover, mice treated with HFD + S1 or S2 had lower Tg levels compared to mice treated with the HFD at 24 weeks ( $p<0.05$ for both), without any significant difference between S1 and S2 groups. 
Table III. Effect of HFD + S1 and HFD + S2 compared to SD or HFD on metabolic parameters during the period of evaluation

\begin{tabular}{|c|c|c|c|c|c|c|c|c|}
\hline \multirow[t]{3}{*}{ Group } & \multicolumn{8}{|c|}{ Time (days) } \\
\hline & \multicolumn{4}{|c|}{ Baseline } & \multicolumn{4}{|c|}{24 weeks } \\
\hline & SD & HFD & $\mathrm{HFD}+\mathrm{S} 1$ & $\mathrm{HFD}+\mathrm{S} 2$ & SD & HFD & $\mathrm{HFD}+\mathrm{S} 1$ & $\mathrm{HFD}+\mathrm{S} 2$ \\
\hline$N$ & 12 & 12 & 13 & 13 & 12 & 12 & 13 & 13 \\
\hline$M / F$ & $6 / 6$ & $6 / 6$ & $7 / 6$ & $6 / 7$ & $6 / 6$ & $6 / 6$ & $7 / 6$ & $6 / 7$ \\
\hline Weight [g] & $\begin{array}{l}29.4 \\
\pm 2.7\end{array}$ & $\begin{array}{c}35.2 \\
\pm 5.6^{*}\end{array}$ & $\begin{array}{c}34.7 \\
\pm 4.2^{*}\end{array}$ & $\begin{array}{c}36.8 \\
\pm 6.1^{*}\end{array}$ & $\begin{array}{l}30.2 \\
\pm 3.1\end{array}$ & $\begin{array}{c}38.7 \\
\pm 6.8^{*}\end{array}$ & $\begin{array}{c}36.5 \\
\pm 5.9^{\star}\end{array}$ & $\begin{array}{c}38.3 \\
\pm 6.4^{*}\end{array}$ \\
\hline BG [mg/dl] & $\begin{array}{l}77.8 \\
\pm 6.1\end{array}$ & $\begin{array}{l}81.4 \\
\pm 8.5\end{array}$ & $\begin{array}{r}79.3 \\
\pm 6.9\end{array}$ & $\begin{array}{l}75.4 \\
\pm 5.8\end{array}$ & $\begin{array}{l}81.8 \\
\pm 8.9\end{array}$ & $\begin{array}{l}84.6 \\
\pm 9.4\end{array}$ & $\begin{array}{l}76.1 \\
\pm 6.0\end{array}$ & $\begin{array}{l}73.4 \\
\pm 5.1\end{array}$ \\
\hline $\mathrm{TC}[\mathrm{mg} / \mathrm{dl}]$ & $\begin{array}{l}103.5 \\
\pm 13.4 \\
\end{array}$ & $\begin{array}{c}117.0 \\
\pm 14.6^{*}\end{array}$ & $\begin{array}{c}114.2 \\
\pm 12.3^{*}\end{array}$ & $\begin{array}{c}119.8 \\
\pm 16.1^{*}\end{array}$ & $\begin{array}{r}98.0 \\
\pm 9.7 \\
\end{array}$ & $\begin{array}{c}121.6 \\
\pm 20.9^{*}\end{array}$ & $\begin{array}{c}91.4 \\
\pm 8.6^{\star \star \AA^{\wedge}}\end{array}$ & $\begin{array}{c}102.1 \\
\pm 12.1^{\circ}\end{array}$ \\
\hline LDL-C [mg/dl] & $\begin{array}{l}16.0 \\
\pm 2.1\end{array}$ & $\begin{array}{l}20.7 \\
\pm 2.9\end{array}$ & $\begin{array}{l}20.2 \\
\pm 2.5\end{array}$ & $\begin{array}{l}20.4 \\
\pm 2.6\end{array}$ & $\begin{array}{l}12.7 \\
\pm 1.6\end{array}$ & $\begin{array}{c}17.5 \\
\pm 2.7^{\star}\end{array}$ & $\begin{array}{c}10.1 \\
\pm 1.8^{\star E^{\wedge}}\end{array}$ & $\begin{array}{c}15.2 \\
\pm 1.9^{\circ}\end{array}$ \\
\hline $\mathrm{HDL}-\mathrm{C}[\mathrm{mg} / \mathrm{dl}]$ & $\begin{array}{l}111.2 \\
\pm 14.5\end{array}$ & $\begin{array}{l}122.2 \\
\pm 19.1\end{array}$ & $\begin{array}{l}123.4 \\
\pm 19.4\end{array}$ & $\begin{array}{l}124.6 \\
\pm 20.7\end{array}$ & $\begin{array}{r}92.4 \\
\pm 3.9\end{array}$ & $\begin{array}{l}118.3 \\
\pm 17.1\end{array}$ & $\begin{array}{l}121.9 \\
\pm 18.9\end{array}$ & $\begin{array}{l}122.5 \\
\pm 19.7\end{array}$ \\
\hline $\operatorname{Tg}[\mathrm{mg} / \mathrm{dl}]$ & $\begin{array}{l}110.4 \\
\pm 21.6\end{array}$ & $\begin{array}{c}136.4 \\
\pm 26.9^{*}\end{array}$ & $\begin{array}{c}138.7 \\
\pm 28.2^{*}\end{array}$ & $\begin{array}{c}140.9 \\
\pm 31.7^{*}\end{array}$ & $\begin{array}{l}115.7 \\
\pm 22.8\end{array}$ & $\begin{array}{c}127.3 \\
\pm 23.6^{*}\end{array}$ & $\begin{array}{c}101.3 \\
\pm 13.6^{\circ}\end{array}$ & $\begin{array}{c}108.4 \\
\pm 17.5^{\circ}\end{array}$ \\
\hline CRP $[\mathrm{mg} / \mathrm{l}]$ & $\begin{array}{c}3.5 \\
\pm 1.9\end{array}$ & $\begin{array}{c}4.0 \\
\pm 2.2^{\star}\end{array}$ & $\begin{array}{c}4.1 \\
\pm 2.3^{*}\end{array}$ & $\begin{array}{c}3.9 \\
\pm 2.1^{*}\end{array}$ & $\begin{array}{c}3.8 \\
\pm 2.1\end{array}$ & $\begin{array}{c}7.0 \\
\pm 3.3^{*}\end{array}$ & $\begin{array}{c}3.6 \\
\pm 2.5^{f^{\wedge}}\end{array}$ & $\begin{array}{c}4.3 \\
\pm 2.5^{\star 0}\end{array}$ \\
\hline
\end{tabular}

Data are mean \pm standard deviation. ${ }^{*} p<0.05$ vs. SD at baseline; ${ }^{5} p<0.01$ vs. SD at baseline; ${ }^{\circ} p<0.05$ vs. HFD at 24 weeks; ${ }^{E} p<0.01$ vs. HFD at 24 weeks; ^p<0.05 vs. HFD + S2 at 24 weeks. SD - standard diet, HFD - high-fat diet, HFD + S1 - high-fat diet + Rossopuro FORTE, HFD + S2 - high-fat diet + Rossopuro.

\section{C-reactive protein}

After 24 weeks, mice treated with the HFD had higher levels of CRP compared to mice treated with the SD. However, mice treated with HFD + S1 and HFD + S2 showed lower levels of CRP compared to mice fed with the HFD alone ( $p<0.01$ vs. HFD at 24 weeks for HFD + S1, and $p<0.05$ vs. HFD at 24 weeks for HFD + S2). Moreover, mice treated with HFD + S1 had lower CRP levels compared to mice fed with HFD + S2 ( $p<0.05$ vs. HFD + S2 at 24 weeks).

\section{Discussion}

In our study we observed a better effect of the combination of monacolin $\mathrm{K}, \gamma$-oryzanol, and $\gamma$-aminobutyric acid compared to monacolin $\mathrm{K}$ alone, probably due to the synergic effect of the various components. Monacolin $\mathrm{K}$ has been extensively studied. Several intervention studies have demonstrated that red yeast rice containing 5 to $10 \mathrm{mg}$ of monacolin $\mathrm{K}$ lowers elevated LDL-C levels by about $22 \%$ to $27 \%$ [12-14]. The European Food Safety Authority considers that a daily intake of $10 \mathrm{mg}$ of monacolin $\mathrm{K}$ from red yeast rice contributes to the maintenance of a normal LDL-C plasma level. Less known is $\gamma$-oryzanol. Rice (Oryza sativa L.) bran is a by-product produced in processing rice. Traditionally, rice bran, produced as a by-product during milling, is considered as waste. However, it is a fact that rice bran comprises up to $10 \%$ of rough rice and is a rich natural source of important antioxidant polyphenolics, flavonoids, phytic acid, vitamin E and $\gamma$-oryzanol. Gamma-oryzanol is an anti-oxidant compound associated with decreases in plasma cholesterol, cholesterol absorption, and platelet aggregation [15]. Oryzanol has also been used to treat hyperlipidemia and disorders of menopause and to increase the muscle mass [16]. On the other side, $\gamma$-aminobutyric acid is one of the many nutritional components in brown rice and pre-germinated brown rice with slight germination. It has been reported that pre-germinated brown rice rich in $\gamma$-aminobutyric acid effectively reduced glucose levels in diabetic rats [17]. $\gamma$-Aminobutyric acid also showed anti-anxiety effects [18] and positive effects against chronic renal failure [19]. $\gamma$-Oryzanol was also suggested to show blood cholesterol lowering [20] and anti-oxidant effects [21].

In conclusion, the study showed that a nutraceutical combination containing monacolin $\mathrm{K} 3 \%$, $\gamma$-oryzanol, and $\gamma$-aminobutyric acid is more effective than monacolin $\mathrm{K} 3 \%$ alone in reducing the negative effects of a HFD in a sample of specific pathogen-free 4-week-old male C57BL/6J mice. These data are really interesting, and are a good starting point for future studies in humans. Of course, nutraceuticals cannot replace an appropriate lifestyle, but should be complementary, and used before starting traditional therapy in low cardio-metabolic risk patients. We also need 
to consider that an improvement of lipid profile does not always translate into a net cardiovascular benefit for the patient. Studies examining "hard" clinical endpoints are necessary to prove the efficacy of a hypolipidemic treatment, because at present nutraceuticals lack such major studies.

\section{Acknowledgments}

The authors thank the staff at Biogem laboratories (Ariano Irpino, Avellino, Italy), for taking and processing blood samples, for their help and advice and for the use of their facilities to conduct this study.

\section{Conflict of interest}

Dr. Rosario Russo is employed by Giellepi S.p.A. Health Science, Lissone, Italy. The other authors declare that they have no conflict of interest. No writing assistance was used in the production of this manuscript.

\section{References}

1. Muller-Nordhorn J, Binting S, Roll S, Willich SN. An update on regional variation in cardiovascular mortality within Europe. Eur Heart J 2008; 29: 1316-26.

2. Banach, M, Jankowski, P, Jóźwiak, J, et al. PoLA/CFPiP/ PCS guidelines for the management of dyslipidaemias for family physicians 2016. Arch Med Sci 2017; 13: 1-45.

3. Vijan S, Hayward RA. American College of Physicians. Pharmacologic lipid-lowering therapy in type 2 diabetes mellitus: background paper for the American College of Physicians. Ann Intern Med 2004; 140: 650-8.

4. McClure DL, Valuck RJ, Glanz M, Hokanson JE. Systematic review and meta-analysis of clinically relevant adverse events from HMG CoA reductase inhibitor trials worldwide from 1982 to present. Pharmacoepidemiol Drug Saf 2007; 16: 132-43.

5. Derosa G, Maffioli P. Nutraceuticals for the treatment of metabolic diseases: evidence from clinical practice. Expert Rev Endocrinol Metab 2015; 10: 297-304.

6. Maierean SM, Serban MC, Sahebkar A, et al.; Lipid and Blood Pressure Meta-analysis Collaboration (LBPMC) Group. The effects of cinnamon supplementation on blood lipid concentrations: a systematic review and meta-analysis. J Clin Lipidol 2017; 11: 1393-406.

7. Cicero AFG, Colletti A, Bajraktari G, et al. Lipid lowering nutraceuticals in clinical practice: position paper from an International Lipid Expert Panel. Arch Med Sci 2017; 13: 965-1005.

8. Ward N, Sahebkar A, Banach M, Watts G. Recent perspectives on the role of nutraceuticals as cholesterollowering agents. Curr Opin Lipidol 2017; 28: 495-501.

9. Ursoniu S, Sahebkar A, Serban MC, et al.; Lipid and Blood Pressure Meta-analysis Collaboration Group. Lipid-modifying effects of krill oil in humans: systematic review and meta-analysis of randomized controlled trials. Nutr Rev 2017; 75: 361-73.

10. Barrios V, Escobar C, Cicero AF, et al. A nutraceutical approach (Armolipid Plus) to reduce total and LDL cholesterol in individuals with mild to moderate dyslipidemia: review of the clinical evidence. Atheroscler Suppl 2017; 24: 1-15.
11. Sahebkar A, Serban MC, Gluba-Brzózka A, et al. Lipidmodifying effects of nutraceuticals: an evidence-based approach. Nutrition 2016; 32: 1179-92.

12. Becker DJ, Gordon RY, Halbert SC, French B, Morris PB, Rader DJ. Red yeast rice for dyslipidemia in statinintolerant patients: a randomized trial. Ann Intern Med 2009; 150: 830-9.

13. Derosa G, D’Angelo A, Romano D, Maffioli P. Effects of a combination of Berberis aristata, Silybum marianum and Monacolin on lipid profile in subjects at low cardiovascular risk; a double-blind, randomized, placebo-controlled trial. Int J Mol Sci 2017; 18: 343.

14. Lin C, Li T, Lai M. Efficacy and safety of Monascus Purpureus went rice in subjects with hyperlipidemia. Eur J Endocrinol 2005; 5: 679-86.

15. Rong N, Ausman LM, Nicolosi RJ. Oryzanol decreases cholesterol absorption and aortic fatty streaks in hamsters. Lipids 1997; 32: 303-9.

16. Patel M, Naik SN. Gamma-oryzanol from rice brain oil-a review. J Sci Ind Res 2004; 63: 569-78.

17. Hagiwara H, Seki T, Ariga T. The effect of pre-germinated brown rice intake on blood glucose and PAI-1 levels in streptozotocin-induced diabetic rats. Biosci Biotechnol Biochem 2004; 68: 444-7.

18. Jung WY, Kim SG, Lee JS, et al. Effect of feeding high gamma-aminobutyric acid-containing giant embryo black sticky rice (Oryza sativa L.) on anxiety-related behavior of C57BL/6 mice. J Med Food 2017; doi: 10.1089/ jmf.2017.3928.

19. Sasaki S, Yokozawa T, Cho EJ, Oowada S, Kim M. Protective role of gamma-aminobutyric acid against chronic renal failure in rats. J Pharm Pharmacol 2006; 58: 1515-25.

20. Rong N, Ausman LM, Nicolosi RJ. Oryzanol decreases cholesterol absorption and aortic fatty streaks in hamsters. Lipids 1997; 32: 303-9.

21. Xu Z, Hua N, Godber JS. Antioxidant activity of tocopherols, tocotrienols, and gamma-oryzanol components from rice bran against cholesterol oxidation accelerated by 2,2-azobis(2-methylpropionamidine) dihydrochloride. J Agric Food Chem 2001; 49: 2077-81. 